\title{
Mengenali Pengaruh Emosional Pada Suara Manusia Menggunakan Metode Fast Fourier Transform (FFT)
}

\author{
Phita Aulia Ummami ${ }^{1}$, Aprodita Alvy Zagita Sari ${ }^{2}$, Apri Junaidi ${ }^{3}$ \\ Program Studi Teknik Informatika, Fakultas Teknik Industri dan Informatika, \\ Institut Teknologi Telkom Purwokerto \\ ${ }^{1} \underline{15102070 @ s t 3 t e l k o m . a c . i d},{ }^{2} 15102049 @$ st3telkom.ac.id, ${ }^{3}$ aprijunaidi@ittelkom-pwt.ac.id
}

Accepted on 12-08-2019

\begin{abstract}
Emotion is a feeling that is felt by someone and can be addressed to other people or something and can arise as a reaction due to certain events. Some previous studies have stated that some statistical parameters have a high correlation between speech and emotional states that can indirectly influence the state of sound identified. In this study a simple experiment was carried out by taking nine samples with three different emotional characters namely sad, happy, and angry taken from three respondents who were randomly selected with the aim of identifying differences in emotions generated through sound data using the Fast Fourier Transform method ( FFT).
\end{abstract}

Keywords: Emotional, Fast Fourier Transform (FFT), Voice Recognition

\section{INTRODUCTION}

$\mathbf{S}$ ejak lahir manusia telah dikenalkan dan secara tidak langsung belajar mengenai kemampuan emosi yang dapat dirasakan oleh manusia tersebut. Emosi merupakan suatu perasaan yang dirasakan oleh seseorang dan dapat ditujukan kepada orang lain atau sesuatu dan dapat timbul sebagai suatu reaksi akibat kejadian tertentu (Prasetio and Kurniawan, 2017). menurut A. Noguieras pada Barlian terdapat penelitian yang menyatakan bahwa beberapa parameter statistik memiliki korelasi yang tinggi antara ucapan dengan keadaan emosional diantaranya seperti pitch, energi, artikulasi dan bentuk spektral yang secara tidak lansgung dapat mempengaruhi keadaan suara yang diidentifikasi (Prasetio and Kurniawan, 2017).

Suara merupakan sebuah bentuk yang dihasilkan karena suatu sinyal yang dipengaruhi oleh frekuensi berbentuk sinyal diskrit dan dipengaruhi pula oleh waktu. suara yang dimiliki oleh manusia umumnya memiliki keanekaragaman yang dipengaruhi oleh beberapa faktor, diantaranya; formant,jenis suara, pitch, timbre, dan volume(Bhaskoro, Pelatihan and Pengenalan, 2012; Hanggarsari, Fitriawan and Yuniati, 2012). selain pengaruh tersebut, warna suara dapat dipengaruhi pula oleh tingkat frekuensi, amplitudo yang dihasilkan oleh suara iu sendiri. Dalam mengenali emosi dibutuhkan suatu sistem yang dapat mengiddetifikasi melalui suara. Oleh karena itu, pada penelitian ini akan dibangun sebuah sistem yang dapat melakukan teknik perekaman sinyal suara secara realtime lalu sinyal suara yang masih berupa sinyal analog dalam domain waktu nantinya akan dikonversikan ke dalam domain frekuensi menggunakan algoritma Fast Fourier 
Transform (FFT) untuk dapat diproses kembali dalam pengidentifikasian emosi bahagia, sedih dan marah melalui suara.

\section{LITERATURE REVIEW}

\section{A. Suara Manusia}

Suara Manusia dihasilkan dari adanya dua buah proses generation dan filtering dimana pada proses generation suara diproduksi melalui getaran dari pita suara yang berada di larynk untuk menghasilkan bunyi periodik. Bunyi periodik yang masih bersifat konstan nantinya akan di filtering kembali melaui vocal tract atau disebut juga dengan istilah resonator suara atau articulator yang terdiri dari lidah, gigi, bibir dll sehingga dapat menjadi keluaran utuk kebutuhan analisa voice recognition (Hakim, 2016).

\section{B. Teori Sinyal Suara}

Sinyal merupakan suatu gejala fisika dimana karakteristiknya dapat melambangkan informasi. Representasi sinyal yang sering ditemui pada khiduan sehari-hari dapat ditinjau berdasarkan dimensinya contohnya pada dimensi-1 biasanya diterapkan pada sinyal audio. Audio dapat didefinisikan sebagai suara yang dapat dihasilkna ari sebuah benda yang bergetar. Keluaran gelombang suara yang dihasilkan berbentuk gelombang longitudinal yang masih bersifat analog. Gelombang suara inilah yang dimanfaatkan sinyal analog dalam pengiriman suara yang merambat pada material-material tertentu. gelombang suara umumnya memiliki minimal 1 buah lembah dan 1 buah bukit yang menghasilkan satu siklus atau periode. apabila siklus ini berulang-ulang maka akan membawa pada konsep frekuensi dimana frekuensi merupakan jumlah siklus yang terjadi dalam satu detik (Sipasulta, St and Sompie, 2014; Hakim, 2016; Lamtiur, 2018).

\section{Pengenalan Emosi}

Emosi merupakan perasaan yang terjadi pada suatu individu yang melibatkan perubahan fisik maupun karakter seperti denyut nadi, produksi kelenjar, suara dan sebagainya serta biassanya ditujukan terhadap individu yang lain atau sesuatu yang dapat diartikan juga sebagai kondisi reaksi yang ditimbulkan akibat perbuatan atau kejadian tertentu. adapun dari sudut mental dapat ditandai dengan perasaan yang kuat daripada suatu keadaan senang atau cemas yang biasanya didorong menuuju bentuk nyata dari tingkah laku organisme itu sendiri (Nadhiroh, 2015; Prasetio and Kurniawan, 2017).

Emosi dapat muncul saat terjadi perubahan pada kejadian yang menjadi perhatian individu tersebut. perubahan kemunculuan emosi dapat dikenali melalui beberapa ekspresi wajah, suara, sikap, tingkah laku dan sebagainya. ekspresi suara diketahui secara umum dalam kehidupan sehari-hari seperti tertawa, berteriak, memaki ataupun bersenandung. para pakar komunikasi menganggap komunikasi dalam bentuk ekspresi suara lebih mudah dikenali dan dipahami karena aksentuasi dalam berdialog antar individu sangat membantu pemahaman makna yang dimaksud oleh pembicara(Nadhiroh, 2015).

\section{Fast Fourier Transform (FFT)}

Fast Fourier Transform (FFT) merupakan suatu pengembangan dari algoritma sebelumya yaitu Fourier Transform (FT). algoritma yang ditemukan oleh J. Fourier ada 1822 ini merupakan algoritma dengan data struktur array satu dimensi untuk menyimpan data serta merubah data difungsikan untuk merepresentasikan sinyal dalam domain waktu diskrit dan domain frekuensi. adapun definisi lain menyebutkan bahwa FFT merupakan metode yang efisien untuk menghitung koefisien dari fourier diskrit ke suatu finite sekuen dari data analisa sinyal yang komplek seperti pemfilteran, analisa korelasi, dan analisa spektrum (Hanggarsari, Fitriawan and Yuniati, 2012; Sipasulta, St and Sompie, 2014; Ferrdyhendrawan et al., 2017; Sujadi et al., 2017).

Dalam notasi yang kompleks, waktu dan frekuensi domain masing-masing memiliki satu sinyal yang diciptakan dari N kompleks point. Setiap dari kompleks point ini dikomposisikan dari dua angka, bagian real 
dan bagian imaginary. perumusan algoritma Fast Fourier Transform (FFT) dapat ditinjau melalui rumus berikut

$$
\begin{aligned}
& F(k)=\sum_{n=1}^{N} f(n) \cos (2 \pi n k T / N) \\
&-j \sum_{n=1}^{N} f(n) \sin (2 \pi n k T / N)
\end{aligned}
$$

Untuk mendapatkan nilai $\mathrm{j}$ data menggunakan persamaan berikut.

$$
|f(u)|=\left[R^{2}+I^{2}\right]^{1 / 2}
$$

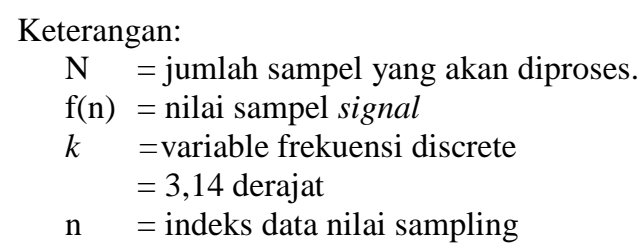

III. RESEARCH METHOD

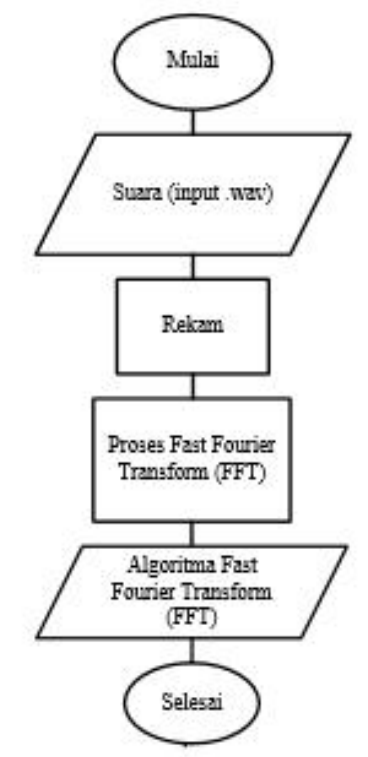

Gambar 1. Diagram Alir Identifikasi Suara

Pada Gambar 1 dapat dilihat diagram alir yang menggambarkan proses identifikasi suara berawal dari penginputan suara dari beberapa sampel data yang diambil dari tiga orang. Format hasil penginputan suara yang masih berekstensi .m4a nantinya akan diubah menjadi file berekstensi .wav. Setelah melakukan input suara, proses selanjutnya ialah perekaman. Proses rekaman merupakan proses masuknya suara manusia. sinyal analog akan diubah menjadi sinyal digital pada saat proses rekaman. selain itu, pada tahap ini akan melalui proses sampling yang bertujuan untuk merekam suara manusia dengan frekuensi yang telah 
ditentukan yakni $8000 \mathrm{~Hz}$. Lama waktu penangkapan ucapan ditentukan sebesar 5 detik. waktu tersebut ditentukan agar suara yang dihasilkan dapat menangkap emosi pemilik suara. Proses sampling dilakukan dengan menentukan panjang durasi perekaman, frekuensi sampling dan jumlah data sampel. Data sampel yang diambil dari tiga orang berbeda dihasilkan sembilan data suara dengan ketentuan emosi yang berbeda saat proses perekaman diantaranya bahagia, sedih dan marah. setelah itu hasil rekaman akan disimpan dalam format wav. Setelah melakukan proses rekam, data yang telah berekstensi .wav akan di proses kembali menggunakan Algoritma Fast Fourier Transform (FFT). Proses ini dimulai dengan mencari nilai komputasi FFT yang dilanjutkan dengan mencari nilai absolute dari hasil komputasi fft tersebut. proses dilanjutkan dengan mencari nilai absolute dari nilai log hasil fft dari perhitungan fft sebelumnya. dari hasil tersebut kemudian di lakukan proses hamming window untuk membuat hasil menjadi lebih halus dalam menghilangkan efek dari diskontinuitas.

Setelah proses penghitungan FFT tersebut tahap selanjutya ialah menampilkan keluaran dari proses sebelumnya, diantaranya di gambarkan dalam bentuk grafik yakni grafik hasil rekaman dan grafik hasil proses FFT. setelah itu hasil dari fft akan digambarkan dalam bentuk spektrogram untuk membayangkan bagaimana frekuensi yang berbeda, yang membentuk gelombang yang berubah seiring waktu.

\section{RESULTS AND DISCUSSION}

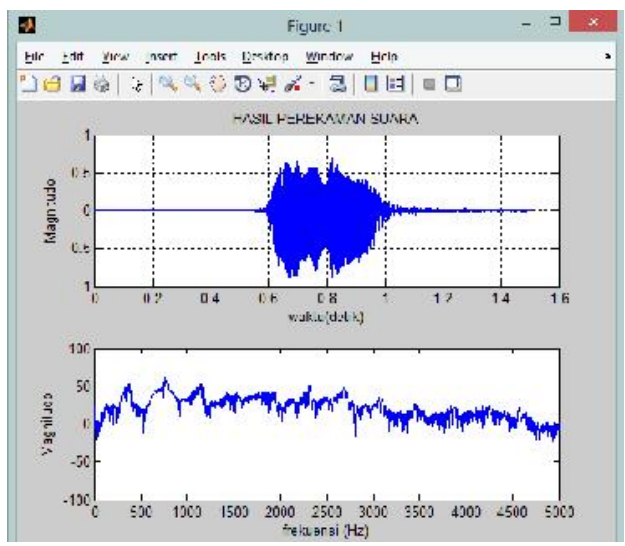

Gambar 2. Grafik Sinyal Suara Berdasarkan Emosi Marah

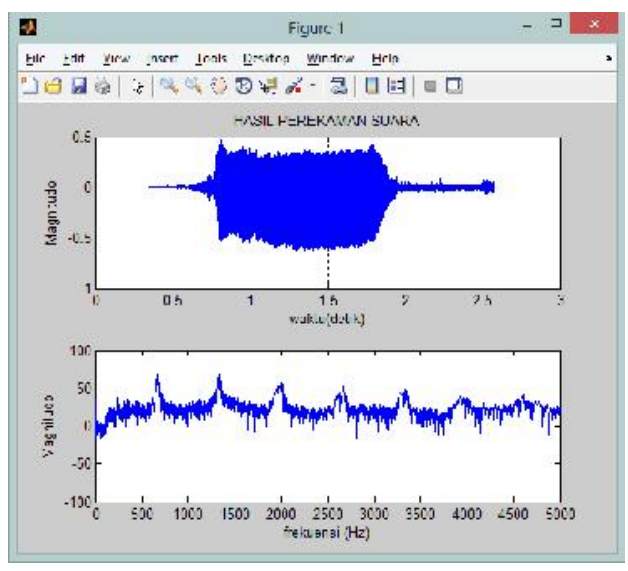

Gambar 4. Grafik Sinyal Suara Berdasarkan Emosi Sedih

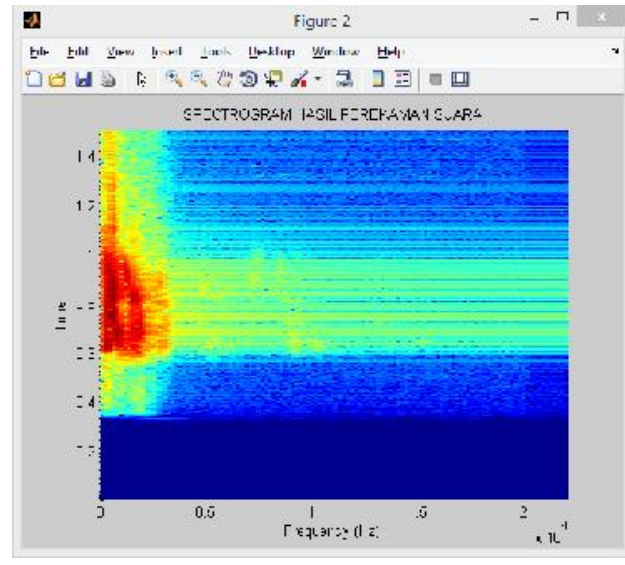

Gambar 3. Spektrogram Berdasarkan Grafik Emosi Marah

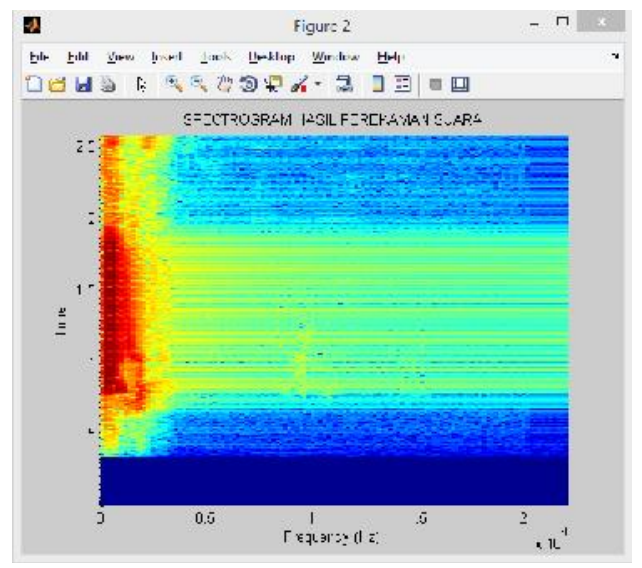

Gambar 5. Spektrogram Berdasarkan Grafik Emosi Sedih 


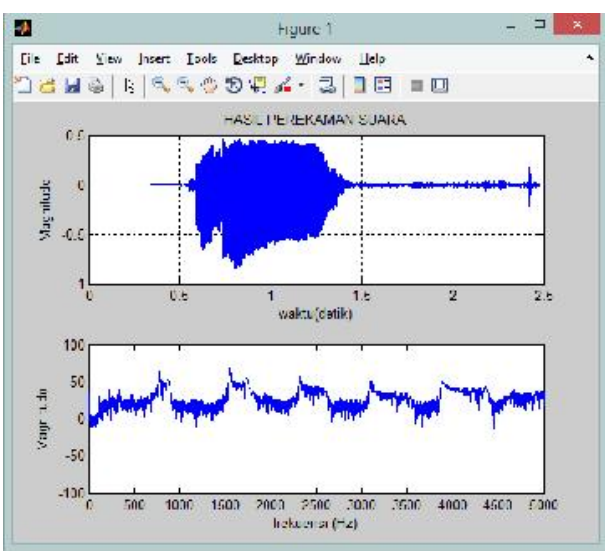

Gambar 6. Grafik Sinyal Suara Berdasarkan Emosi Bahagia

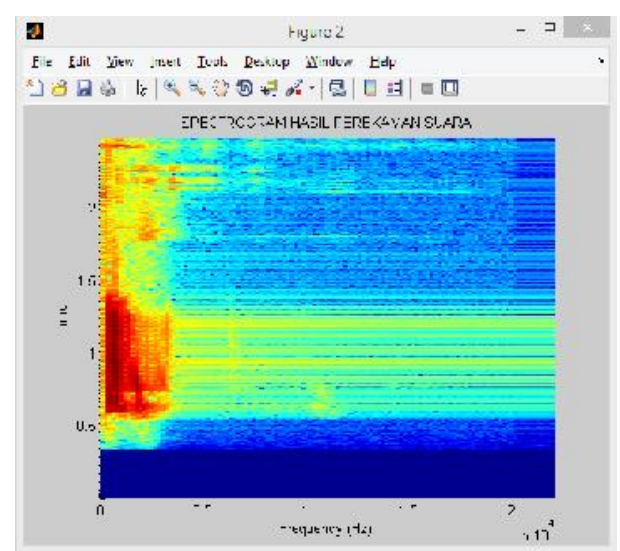

Gambar 7. Spektrogram Berdasarkan Grafik Emosi Bahagia

Dari kesembilan data, akan diambil satu buah sampel dari setiap 3 buah data emosi. Hasil spectrogram dapat dilihat dari gambar-gambar berikut. Berdasarkan hasil, suara rekaman hasil filter FFT mempunyai kisaran frekuensi dari $20 \mathrm{~Hz}$ sampai $20 \mathrm{KHz}$, hal ini sesuai dengan kemampuan rekaman data oleh souncard. Intensitas yang tinggi yaitu pada frekuensi $44 \mathrm{~Hz}$ sampai $3620 \mathrm{~Hz}$ dan intensitas yang paling tinggi yaitu pada frekuensi $115 \mathrm{~Hz}$ sampai $640 \mathrm{~Hz}$. Adapun kisaran suara manusia adalah $50 \mathrm{~Hz}$ sampai $10 \mathrm{KHz}$. Berdasarkan hal tersebut maka dapat dikatakan frekuensi suara $20 \mathrm{~Hz}-49 \mathrm{~Hz}$ dan $10 \mathrm{KHz}-20 \mathrm{KHz}$ pada data rekaman adalah berupa gangguan. Sehingga dapat dikatakan bahwa sumber suara mempunyai karakteristik suara dengan frekuensi $50 \mathrm{~Hz}-3620 \mathrm{~Hz}$ dengan intensitas tertinggi pada $115 \mathrm{~Hz}-640 \mathrm{~Hz}$.

\section{CONCLUSSION}

Karakteristik suara suatu sumber suara dapat diketahui dengan membandingkan dan menghubungkan parameter-parameter suara. Dengan melihat hubungan antara frekuensi, intensitas, dan waktu dari sumber suara, maka kita dapat mengetahui karakteristik sumber suara tersebut. Proses filter FFT berfungsi untuk menghilangkan gannguan yang tidak diinginkan sehingga data rekaman yang didapat kualitasnya lebih baik karena amplitudonya tidak terlalu berfluktuasi.

Pada proses perekaman suara, diharapkan pada kondisi yang tenang (tidak ada suara selain suara dari sumber), sehingga hasil analisis dapat menggambarkan dengan tepat karakter suara sumber. sebelum dilakukan pengolahan menggunakan FFT, sampel suara dapat dilakukan preprocessing terlebih dahulu untuk mendapatkan hasil yang lebih baik pada FFT

\section{REFERENCES}

Bhaskoro, S. B., Pelatihan, F. and Pengenalan, F. (2012) 'Aplikasi pengenalan gender menggunakan suara', 2012(Snati), pp. $15-16$

Ferrdyhendrawan, T. et al. (2017) 'SOUND CONVERSION USING FAST FOURIER TRANSFORM', 1(1), pp. 22-26.

Hakim, A. R. (2016) 'Analisis Perbandingan Discrete Wavelet Transform , Discrete Cosine Transform dan Fourier Transform pada Proses Pengenalan Pola Suara'.

Hanggarsari, P. N., Fitriawan, H. and Yuniati, Y. (2012) 'SIMULASI SISTEM PENGACAKAN SINYAL SUARA SECARA REALTIME BERBASIS FAST FOURIER TRANSFORM ( FFT )’, (3), pp. 192-198.

Lamtiur, R. A. (2018) Identifikasi Sinyal Suara Menggunakan Metode Fast Fourier Transform ( FFT ) Berbasis Matlab.

Nadhiroh, Y. F. (2015) 'PENGENDALIAN EMOSI (Kajian Religio-Psikologis tentang Psikologi Manusia)', 2(1), pp. 53-63.

Prasetio, B. H. and Kurniawan, W. (2017) 'Pengenalan Emosi Berdasarkan Suara Menggunakan Algoritma HMM', (December). doi: 10.25126/jtiik.201743339.

Sipasulta, R. Y., St, A. S. M. L. and Sompie, S. R. U. A. (2014) 'Simulasi Sistem Pengacak Sinyal Dengan Metode FFT ( Fast Fourier Transform )', pp. 1-9. 
Sujadi, H. et al. (2017) 'SISTEM PENGOLAHAN SUARA MENGGUNAKAN ALGORITMA FFT’, pp. 101-107. 